\title{
Preference in the use of full childhood immunizations in Ethiopia: the role of maternal health services
}

This article was published in the following Dove Medical Press journal: Patient Preference and Adherence

\author{
Nigatu Regassa ${ }^{1,2}$ \\ Yelena Bird ${ }^{2}$ \\ John Moraros²
}

'Hawassa University, Hawassa, Ethiopia; ${ }^{2}$ School of Public Health, University of Saskatchewan, Saskatoon, Canada
Correspondence: John Moraros School of Public Health, University of Saskatchewan, 104 Clinic Place, E-Wing Health Sciences, Room 3320, Saskatoon, SK S7N 2Z4, Canada

Tel +I 3069668578

Email john.moraros@usask.ca
Background: Immunizations represent a successful and cost-effective public health strategy in preventing common childhood diseases. Ethiopia has made remarkable progress in increasing its full immunization coverage, but significant gaps remain. This study aims to measure the preference in the use of full immunizations for children aged 12-23 months in Ethiopia and examine the role of key maternal health services.

Methods: This is a cross-sectional study and uses data from a nationally generalizable survey, the Ethiopian Demographic and Health Survey, 2016. It includes a representative sample of 2,168 children aged 12-23 months. The main outcome was full immunization, measured based on the WHO guidelines (Bacillus Calmette-Guérin [BCG], diphtheria, tetanus, and pertussis [DPT], polio, and measles vaccines). The main exposure variables were provision of three key maternal health services (antenatal care, delivery services, and tetanus vaccine) as well as other sociodemographic factors. Descriptive statistics and multivariate logistic regression analyses were conducted.

Results: This study found the overall full immunization coverage in Ethiopia to be much lower (39\%) than the WHO-recommended rate $(\geq 90 \%)$. There were distinctive differences in the preference in the use of full immunization coverage for various vaccines (BCG 70.0\%, polio $56.5 \%$, measles 55.3\%, and DPT 53.9\%). The maternal health service variables (antenatal care, delivery services, and tetanus vaccine) were significantly associated with the full immunization of children aged $12-23$ months $(P<0.001)$. In the full model, the maternal health service variables remained significant, along with other socioeconomic predictors of full immunization, including sex of the household head $(P<0.001)$, maternal education $(P<0.05)$, wealth index $(P<0.01)$, and religion $(P<0.001)$.

Conclusion: Full immunization coverage has been identified as a critical factor in the prevention of morbidity and mortality from childhood diseases. Future progress in the provision of key maternal health services can have a positive impact in narrowing the gap in immunization coverage.

Keywords: Africa, Ethiopia, childhood immunizations, maternal health services

\section{Background}

Immunizations represent one of the most cost-effective and successful public health strategies in preventing the occurrence of common childhood diseases, especially in developing countries. ${ }^{1,2}$ Childhood immunizations have led to significant reductions in morbidity and mortality ${ }^{3,4}$ and are estimated to save the lives of $>3$ million children annually. ${ }^{5-8}$ However, nearly 1.5 million children still die every year due to vaccinepreventable diseases. ${ }^{9}$ In 2017 alone, it was reported that nearly 20 million children 
worldwide did not receive their recommended immunizations and $>60 \%$ of them lived in low-income countries, including Ethiopia. ${ }^{9}$

Historically, Ethiopia has experienced the highest rates of child mortality in the world (88 deaths per 1,000 live births, respectively). ${ }^{10}$ In view of these unacceptably high rates, the Ethiopian government developed a national immunization plan in $2007^{11}$ and used the WHO guidelines ${ }^{12}$ to help inform its vaccination schedule for children and women of reproductive age. ${ }^{13,14}$ The WHO guidelines define "complete/ full immunization" as having received all eight Expanded Program on Immunization (EPI)-recommended vaccine doses (one dose of Bacillus Calmette-Guérin [BCG] against tuberculosis; three doses of diphtheria, tetanus, and pertussis [DPT] to prevent diphtheria, pertussis, and tetanus; at least three doses of polio; and one dose of the measles vaccine). ${ }^{6}$

Ethiopia has made remarkable progress in increasing its full immunization coverage among children aged $12-23$ months from $14 \%$ in 2000 to $39 \%$ in $2016 .{ }^{7,15}$ However, despite Ethiopia's commitment to improve accessibility and provision of immunization services to its wider population, ${ }^{16}$ significant gaps remain, and the full immunization coverage is still well below the recommended WHO target (>90\%). Additionally, Ethiopia exhibits significant regional variation in immunization rates, which ranges from a low rate of $9 \%$ in the rural Afar region to a high rate of $79 \%$ in the capital city of Addis Ababa. ${ }^{17}$

A few studies in Ethiopia have examined this important public health issue and helped identify a number of barriers to achieving full immunization. These barriers include poor access to healthcare services, low number of trained personnel, high staff turnover, lack of transportation, distance from healthcare facilities, inadequate awareness of mothers/ caregivers, fear of vaccine side effects, and high dropout rates. ${ }^{17-19}$ Additional studies have shown that several maternal socioeconomic (education and income) and demographic factors (age, number of children, and urban residence) influence the likelihood of full immunizations for children. ${ }^{11,20-23}$

However, most of these studies in Ethiopia were conducted locally, used regional level data, and had small sample sizes, which limit their generalizability. Interestingly, none of these studies examined the specific role of maternal healthcare services (antenatal care, delivery services, and tetanus vaccine) in determining the extent of full immunization at the national level among children in Ethiopia. Previous studies have shown that immunizing the mother prior to childbirth with the tetanus vaccine protects both the mother and her newborn ${ }^{24,25}$ and becomes an excellent point of entry to receiving antenatal care, delivery services, and routine immunization after the child is born. ${ }^{9,26-28}$ Therefore, this study aims to measure the preference in the use of full immunizations for children aged 12-23 months in Ethiopia and examine the role of key maternal health services.

\section{Methodology Study context}

Ethiopia has an estimated population of 105 million people, making it the second most populous country of Africa. ${ }^{29}$ The population is characterized by disproportionately high mortality and fertility rates, and it is currently growing at a rate of $2.6 \%$ per annum. ${ }^{30}$ Administratively, Ethiopia has nine regional states, each one further divided into zones, districts, and sub-districts. The country has an agrarian economy, where agriculture accounts for $>60 \%$ of its gross domestic product (GDP) and employs nearly $85 \%$ of its population. ${ }^{14}$ In Ethiopia, infectious and communicable diseases account for $60 \%-80 \%$ of the health problems. ${ }^{6}$ The country also suffers from poor healthcare infrastructure and high levels of health disparities. ${ }^{31}$ Despite efforts in ensuring universal access to healthcare through the National Health Sector Development Program, ${ }^{32}$ the country is still experiencing high childhood mortality mainly due to poor immunization coverage of vaccine-preventable diseases..$^{17,33}$

\section{Data sources}

The Ethiopia Demographic and Health Surveys (EDHS) are used to collect sociodemographic characteristics and key maternal and child health information from a nation-wide representative sample of households. EDHS are carried out nationally by the Central Statistical Agency under the guidance of the Ministry of Health and with the technical support of ORC Macro International. ${ }^{28,30}$ The data were collected by a two-stage sampling method and used standardized household questionnaires. Maternal and child health information were obtained from eligible women aged 15-49 years in each household surveyed. A total weighted sample of 2,168 children participated in this study.

\section{Variables and measures}

For the purposes of this study, selected household information on sociodemographics, child and mother's health, and birth histories were used. The main outcome variable was full vaccination. Since our unit of analysis was children aged 12-23 months, only women of reproductive age, who had reported having a child within the reference time period were considered $(\mathrm{N}=2,168)$. Immunization status was divided into 
two categories: complete/full, if the child had received all eight recommended doses of vaccinations, and incomplete, if the child missed one or more of the recommended doses.

The main exposure variables of interest were composed of antenatal care, delivery services, and tetanus vaccine. Antenatal care services included provision of health education sessions and clinical physical examinations for the pregnant woman and were divided into two categories as follows: women who attended at least four antenatal care visits and those with $<4$ visits. Delivery services were also grouped into two categories as follows: mothers who delivered their last child in a healthcare setting (hospitals and private and government clinics) and those who delivered at other settings (home). Tetanus vaccination was also grouped into two categories as follows: mothers who received at least two vaccinations during their pregnancy (as recommended by $\mathrm{WHO})^{34}$ and those who did not.

The impact of these exposure variables, along with other key socioeconomic characteristics, on the preference of the use of full childhood immunizations was investigated in this study. Household economic status was measured by the use of a wealth index, which EDHS constructed from selected key household assets. ${ }^{28}$ Information on parental education was measured as the reported number of years of maternal/ paternal education and then allocated within conventional educational categories (eg, no education, primary level, secondary level, and post-secondary level education).

\section{Statistical analyses}

Data cleaning, management, and analysis were carried out by using SPSS Statistics Version 20 (IBM Corporation, Armonk, NY, USA). Sample weights were applied in our analysis as recommended by EDHS ${ }^{28}$ to compensate for the unequal probability of participant selection between the different geographical regions as well as to account for non-responses.

Descriptive statistics were used to examine the distributions of the main outcome, the exposure variables, and other demographic and socioeconomic characteristics. The associations between these factors were assessed using logistic regression. The analysis was performed in two stages. First, only the main exposure variables (antenatal care, delivery services, and tetanus vaccine) were taken into consideration and examined to determine their individual and combined effects on the main outcome (full immunization). Second, multivariable logistic regression modeling was conducted, and a $P$-value of $\leq 0.05$ was considered to be statistically significant. Manual backward selection was used for our model building. A change in regression coefficient of $20 \%$ or more $(\Delta \beta \geq 20 \%)$ was used to determine whether variables were confounders. ${ }^{35}$ The goodness of fit in our final model was tested using the Hosmer-Lemeshow test. ${ }^{36}$

\section{Ethics statement}

EDHS followed previously approved standard protocols, data collection tools, and procedures. Participation in the survey was voluntary. Permission to use the data for the purposes of this study was granted by ORC Macro International (USA) and the Central Statistical Agency (Ethiopia). Ethical approval was also received from the University of Saskatchewan, Behavioral Research Ethics Committee (BEH 18-21).

\section{Results}

Table 1 presents the socioeconomic characteristics of the respondents. The analysis included a total of 2,168 children between 12 and 23 months of age. The majority of the children were female (53.7\%), lived in an urban setting

Table I Sociodemographic characteristics of study participants (EDHS 20I6, $\mathrm{N}=\mathrm{I}$,989)

\begin{tabular}{|c|c|c|}
\hline Characteristics & $\mathbf{n}$ & $\%$ \\
\hline $\begin{array}{l}\text { Sex of the child } \\
\text { Male } \\
\text { Female }\end{array}$ & $\begin{array}{l}921 \\
1,068\end{array}$ & $\begin{array}{l}46.3 \\
53.7\end{array}$ \\
\hline $\begin{array}{l}\text { Place of residence } \\
\text { Rural } \\
\text { Urban }\end{array}$ & $\begin{array}{l}231 \\
I, 758\end{array}$ & $\begin{array}{l}11.6 \\
88.4\end{array}$ \\
\hline $\begin{array}{l}\text { Household size } \\
\qquad \begin{array}{l}\text { I-3 } \\
4-7 \\
7+\end{array}\end{array}$ & $\begin{array}{l}220 \\
1,035 \\
734\end{array}$ & $\begin{array}{l}11.1 \\
52.0 \\
36.9\end{array}$ \\
\hline $\begin{array}{l}\text { Wealth index } \\
\text { Poorest } \\
\text { Poorer } \\
\text { Middle } \\
\text { Richer } \\
\text { Richest } \\
\end{array}$ & $\begin{array}{l}504 \\
390 \\
447 \\
360 \\
287\end{array}$ & $\begin{array}{l}25.3 \\
19.6 \\
22.5 \\
18.1 \\
14.1 \\
\end{array}$ \\
\hline $\begin{array}{l}\text { Age of mothers, years } \\
\qquad 20 \\
20-34 \\
35-49\end{array}$ & $\begin{array}{l}493 \\
1,047 \\
449\end{array}$ & $\begin{array}{l}24.8 \\
52.6 \\
22.6\end{array}$ \\
\hline $\begin{array}{l}\text { Education level of mother } \\
\text { No education } \\
\text { Primary level } \\
\text { Secondary level and above }\end{array}$ & $\begin{array}{l}1,251 \\
568 \\
169\end{array}$ & $\begin{array}{l}62.9 \\
28.6 \\
8.5\end{array}$ \\
\hline $\begin{array}{l}\text { Education level of father } \\
\text { No education } \\
\text { Primary level } \\
\text { Secondary level and above }\end{array}$ & $\begin{array}{l}1,006 \\
738 \\
245\end{array}$ & $\begin{array}{l}50.6 \\
37.1 \\
12.3\end{array}$ \\
\hline
\end{tabular}

Abbreviation: EDHS, Ethiopia Demographic and Health Surveys. 
$(88.4 \%)$, in a medium-sized household $(4-7$ people $=52.0 \%)$, with poorest wealth index (25.3\%), and were born to mothers in their main reproductive years $(20-34$ years $=52.6 \%)$ and with no education (62.9\%).

Table 2 presents the preference in the use of recommended childhood immunizations (DPT3, Polio3, measles, and BCG) among children aged 12-23 months in Ethiopia. The most widely used vaccine was BCG (70.0\%), followed by polio (56.5\%), DPT (53.9\%), and measles (55.3\%).

There was no difference in the overall preference of vaccine use based on the sex of the child. However, there was a higher proportion of vaccinations for children who were first born, Orthodox Christian, lived in an urban setting, belonged to the richest wealth index, and whose mothers and fathers had a secondary level or higher education. The overall prevalence of non-immunized children in Ethiopia was nearly $16 \%$ and varied by birth order, religion, parental education, and wealth index.

In Table 3, the full immunization status of the study participants and crude associations between variables are presented. The overall prevalence of fully immunized children in Ethiopia was 39\%. The crude associations showed that children were significantly more likely to be fully immunized if they were female $(40.0 \%)$, living in an urban setting $(66 \%)$, born to mothers who were Orthodox Christian (50.4\%), in a monogamous relationship (41.0\%), of lower parity (1-3 children $=44.6 \%$, with secondary level or higher education (71.0\%), and access to media (radio) $(P<0.001)$. Additionally, individual and full vaccination coverage increased progressively from the poorest to the richest wealth index $(P<0.001)$. Finally, the provision of maternal health services proved to be important as children whose mothers received the recommended two doses of the tetanus vaccine, number of antenatal care services ( $>4$ times), and gave birth in healthcare facilities were significantly more likely to be fully immunized $(P<0.001)$.

In Table 4 , the results of our binary logistic regression analysis are presented. Model 1 only includes the maternal health service variables (antenatal care [OR $=2.203]$, delivery services [OR $=2.067$ ], and tetanus vaccine [OR $=1.826]$ ) and found them to be significantly associated with full immunization $(P<0.001)$. Model 2 (full model) contains the

Table 2 Preference in the use of recommended childhood immunizations (EDHS, 2016, Ethiopia, N=2, I68)

\begin{tabular}{|c|c|c|c|c|c|c|}
\hline \multirow[t]{2}{*}{ Variables } & \multirow[t]{2}{*}{$\mathbf{n}$} & \multicolumn{4}{|c|}{ WHO-recommended vaccinations } & \multirow[t]{2}{*}{ No immunization (\%) } \\
\hline & & BCG (\%) & $\begin{array}{l}3 \text { doses of } \\
\text { DPT (\%) }\end{array}$ & $\begin{array}{l}3 \text { doses of } \\
\text { polio (\%) }\end{array}$ & $\begin{array}{l}\text { I dose of } \\
\text { measles (\%) }\end{array}$ & \\
\hline \multicolumn{7}{|l|}{ Sex of the child } \\
\hline Male & 921 & 69.5 & 54.3 & 56.6 & 53.6 & 15.8 \\
\hline Female & 1,068 & 70.5 & 53.6 & 56.4 & 56.8 & 15.6 \\
\hline \multicolumn{7}{|l|}{ Residence } \\
\hline Urban & 231 & 89.2 & 80.5 & 80.2 & 76.3 & 3.4 \\
\hline Rural & ।,758 & 67.5 & 49.7 & 53.4 & 52.6 & 17.3 \\
\hline \multicolumn{7}{|l|}{ Education level of mother } \\
\hline No education & $1,25 \mathrm{I}$ & 65.3 & 46.3 & 49.6 & 50.4 & 18.6 \\
\hline Primary level & 568 & 74.8 & 63.0 & 65.1 & 59.1 & 12.0 \\
\hline Secondary level and higher & 169 & 88.8 & 80.0 & 78.6 & 79.3 & 7.2 \\
\hline \multicolumn{7}{|l|}{ Education level of father } \\
\hline No education & 1,006 & 66.0 & 46.1 & 50.3 & 51.1 & 18.5 \\
\hline Primary level & 738 & 71.4 & 58.3 & 59.5 & 55.8 & 13.4 \\
\hline Secondary level and higher & 245 & 82.0 & 72.7 & 73.2 & 71.0 & 11.1 \\
\hline \multicolumn{7}{|l|}{ Wealth index } \\
\hline Poorest & 504 & 59.9 & 38.1 & 43.4 & 44.0 & 23.8 \\
\hline Poorer & 390 & 67.8 & 51.9 & 54.7 & 52.1 & 15.9 \\
\hline Middle & 447 & 69.8 & 51.7 & 57.1 & 55.4 & 14.0 \\
\hline Richer & 360 & 77.0 & 62.5 & 61.7 & 58.4 & 12.2 \\
\hline Richest & 287 & 84.3 & 77.0 & 76.5 & 75.6 & 8.2 \\
\hline \multicolumn{7}{|l|}{ Religion } \\
\hline Orthodox Christian & 694 & 79.5 & 67.0 & 66.5 & 65.6 & 9.1 \\
\hline Muslim & 780 & 59.5 & 42.2 & 45.9 & 43.5 & 22.0 \\
\hline Others & 515 & 72.3 & 54.2 & 59.1 & 58.4 & 15.3 \\
\hline \multicolumn{7}{|l|}{ Birth order } \\
\hline First born & 369 & 73.7 & 60.4 & 61.5 & 61.0 & 13.5 \\
\hline Second to fourth born & 1,620 & 69.1 & 52.5 & 55.8 & 54.0 & 16.2 \\
\hline
\end{tabular}

Abbreviations: BCG, Bacillus Calmette-Guérin; DPT, diphtheria, tetanus, and pertussis; EDHS, Ethiopia Demographic and Health Surveys. 
Table 3 Full immunization status of study participants (EDHS 2016, Ethiopia, $\mathrm{N}=2,168$ )

\begin{tabular}{|c|c|c|c|}
\hline \multirow[t]{2}{*}{ Variables } & \multicolumn{3}{|c|}{$\begin{array}{l}\text { Full immunization in children } \\
\text { aged I } 2-23 \text { months }\end{array}$} \\
\hline & $\mathbf{n}$ & n (\%) & $P$-value \\
\hline $\begin{array}{l}\text { Sex of the household head } \\
\text { Male } \\
\text { Female }\end{array}$ & $\begin{array}{l}1,699 \\
290\end{array}$ & $\begin{array}{l}68 I(40.1) \\
86(29.7)\end{array}$ & 0.000 \\
\hline $\begin{array}{l}\text { Sex of the child } \\
\text { Male } \\
\text { Female }\end{array}$ & $\begin{array}{l}922 \\
1,067\end{array}$ & $\begin{array}{l}336(36.5) \\
430(40.0)\end{array}$ & 0.045 \\
\hline $\begin{array}{l}\text { Residence } \\
\text { Urban } \\
\text { Rural }\end{array}$ & $\begin{array}{l}231 \\
1,758\end{array}$ & $\begin{array}{l}152(65.8) \\
615(35.0)\end{array}$ & 0.000 \\
\hline $\begin{array}{l}\text { Parity } \\
\qquad \text { I-3 children } \\
4-6 \text { children } \\
\geq 7 \text { children }\end{array}$ & $\begin{array}{l}955 \\
658 \\
376\end{array}$ & $\begin{array}{l}426(44.6) \\
233(35.4) \\
108(28.7)\end{array}$ & 0.000 \\
\hline $\begin{array}{l}\text { Education level of mother } \\
\text { No education } \\
\text { Primary level } \\
\text { Secondary level and higher }\end{array}$ & $\begin{array}{l}1,252 \\
568 \\
169\end{array}$ & $\begin{array}{l}386(30.8) \\
26 \mid(46.0) \\
120(71.0)\end{array}$ & 0.000 \\
\hline $\begin{array}{l}\text { Education level of father } \\
\text { No education } \\
\text { Primary level } \\
\text { Secondary level and higher }\end{array}$ & $\begin{array}{l}1,007 \\
738 \\
245\end{array}$ & $\begin{array}{l}309(30.7) \\
310(42.0) \\
148(60.4)\end{array}$ & 0.000 \\
\hline $\begin{array}{l}\text { Wealth index } \\
\text { Poorest } \\
\text { Poorer } \\
\text { Middle } \\
\text { Richer } \\
\text { Richest }\end{array}$ & $\begin{array}{l}504 \\
390 \\
448 \\
360 \\
287\end{array}$ & $\begin{array}{l}\text { I I } 2(22.2) \\
\text { I } 5 \text { I (38.7) } \\
\text { I } 63(36.4) \\
\text { I } 57(43.6) \\
\text { I } 83(63.8)\end{array}$ & 0.000 \\
\hline $\begin{array}{l}\text { Type of family structure } \\
\text { Monogamy } \\
\text { Polygamy }\end{array}$ & $\begin{array}{l}1,686 \\
197\end{array}$ & $\begin{array}{l}691(4 I .0) \\
47(23.9)\end{array}$ & 0.000 \\
\hline $\begin{array}{l}\text { Antenatal service visits } \\
\quad<4 \\
>4\end{array}$ & $\begin{array}{l}1,268 \\
623\end{array}$ & $\begin{array}{l}364(28.7) \\
367(58.9)\end{array}$ & 0.000 \\
\hline $\begin{array}{l}\text { Religion } \\
\text { Orthodox Christian } \\
\text { Muslim } \\
\text { Others }\end{array}$ & $\begin{array}{l}694 \\
780 \\
515\end{array}$ & $\begin{array}{l}350(50.4) \\
205(26.3) \\
212(4 I .2)\end{array}$ & 0.000 \\
\hline $\begin{array}{l}\text { Birth order } \\
\text { First born } \\
\text { Second to fourth born }\end{array}$ & $\begin{array}{l}369 \\
1,620\end{array}$ & $\begin{array}{l}174(47.2) \\
593(36.6)\end{array}$ & 0.000 \\
\hline $\begin{array}{l}\text { Access to media (radio) } \\
\text { Not at all } \\
\text { At least once a week } \\
\text { Less than once in a week }\end{array}$ & $\begin{array}{l}I, 445 \\
27 I \\
274\end{array}$ & $\begin{array}{l}478(33.1) \\
147(54.2) \\
142(51.8)\end{array}$ & 0.000 \\
\hline $\begin{array}{l}\text { Place of delivery } \\
\text { Home } \\
\text { Healthcare institutions }\end{array}$ & $\begin{array}{l}1,259 \\
730\end{array}$ & $\begin{array}{l}371 \text { (29.5) } \\
396(54.2)\end{array}$ & 0.000 \\
\hline
\end{tabular}

Abbreviation: EDHS, Ethiopia Demographic and Health Surveys.

maternal health service as well as other key sociodemographic variables. The results show that maternal health service variables are still significant predictors of full immunization $(P<0.001)$ as were maternal education (secondary level or higher [OR $=1.436]$ ), wealth index (richest $[\mathrm{OR}=1.961]$ ), and religion (Christian Orthodox [OR $=0.451]),(P<0.000)$.

Figure 1 presents the national trends of full immunization coverage over a period of 17 years (2000-2016) in Ethiopia. It is noted that complete immunization coverage among children aged 12-23 months has shown remarkable and steady improvement during this time period, starting with as low as $14 \%$ in 2000 , and then gradually increasing to $20 \%$ in $2005,24 \%$ in 2011 , and finally $39 \%$ in 2016 .

\section{Discussion}

Our results show that despite the remarkable progress made in the last couple of decades, the overall full immunization coverage in Ethiopia remains low (38\%) and well below the herd immunity levels $(80 \%)^{6}$ desired to prevent the spread of common vaccine-preventable diseases and the WHOrecommended target $(\geq 90 \%)$ ). ${ }^{6,37}$ By comparison, a number of other African countries have made more substantive gains in providing full immunization coverage to their population, including Senegal (62.8\%), ${ }^{5}$ Gambia (72.5\%), Ghana (78.8\%), and Burkina Faso (81.0\%). ${ }^{38}$

We found that the mothers' utilization of antenatal care services significantly increased the likelihood of their children receiving full immunization. Comparable nationallevel studies in Ethiopia are scarce, and the few regional studies that have been conducted lend support to our findings. ${ }^{18,39,40}$ More broadly, our results are also consistent with those reported in a number of other sub-Saharan African countries..$^{26-28,41}$ The importance of antenatal care services is critical for both expecting mothers and their newborn children as it provides an opportunity to discuss with health professionals the importance of immunizations, the schedule of vaccine initiation and completion, and the dissemination of accurate information with regard to possible vaccine side effects. ${ }^{42,43}$ Additionally, such visits may help build rapport, trust, and familiarity and could motivate women to use the healthcare facility for their delivery services. ${ }^{42-44}$

In this study, there was a strong positive association between delivery services in a healthcare facility and full immunization. Our results are in line with those reported in the few regional studies previously conducted in Ethiopia and more widely in other parts of Africa, which found that children born in healthcare facilities were more likely to receive full immunizations than those born at home. .,39-41 $^{5}$ The reason for this finding may well be that hospitals and healthcare centers, as matter of policy, provide newborns with immediate vaccinations and inform the new mothers about the health benefits of having their children participate and complete the recommended vaccination regimens. ${ }^{17,41}$ 
Table 4 Multiple logistic regression analysis of the determinants of full immunization

\begin{tabular}{|c|c|c|c|c|c|c|c|c|}
\hline \multirow[t]{3}{*}{ Variables } & \multicolumn{4}{|c|}{ Model I } & \multicolumn{4}{|c|}{ Model 2} \\
\hline & \multirow[t]{2}{*}{ OR } & \multicolumn{2}{|l|}{ Cl 95\% } & \multirow[t]{2}{*}{$P$-value } & \multirow[t]{2}{*}{ OR } & \multicolumn{2}{|l|}{ Cl $95 \%$} & \multirow[t]{2}{*}{$P$-value } \\
\hline & & Lower & Upper & & & Lower & Upper & \\
\hline $\begin{array}{l}\text { Antenatal service visits } \\
\quad<4 \\
>4\end{array}$ & 2.203 & $\mathrm{I} .784$ & 2.720 & 0.000 & 1.990 & 1.579 & 2.507 & 0.000 \\
\hline $\begin{array}{l}\text { Place of delivery } \\
\text { Home } \\
\text { Institutions }\end{array}$ & 2.067 & 1.689 & 2.529 & 0.000 & 1.482 & 1.166 & 1.885 & 0.001 \\
\hline $\begin{array}{l}\text { Received tetanus vaccine } \\
\text { No } \\
\text { Yes }\end{array}$ & 1.826 & 1.492 & 2.235 & 0.000 & 1.818 & 1.463 & 2.259 & 0.000 \\
\hline $\begin{array}{l}\text { Education level of mother } \\
\text { No education } \\
\text { Primary level } \\
\text { Secondary level and higher }\end{array}$ & - & - & - & - & $\begin{array}{l}1.378 \\
1.436\end{array}$ & $\begin{array}{l}1.066 \\
0.819\end{array}$ & $\begin{array}{l}1.780 \\
2.516\end{array}$ & $\begin{array}{l}0.047 \\
0.014\end{array}$ \\
\hline $\begin{array}{l}\text { Wealth index } \\
\text { Poorest } \\
\text { Poorer } \\
\text { Middle } \\
\text { Richer } \\
\text { Richest }\end{array}$ & - & - & - & - & $\begin{array}{l} \\
1.649 \\
1.366 \\
1.122 \\
1.961\end{array}$ & $\begin{array}{l}1.197 \\
0.997 \\
0.801 \\
1.222\end{array}$ & $\begin{array}{l}2.272 \\
1.871 \\
1.570 \\
3.146\end{array}$ & $\begin{array}{l}0.003 \\
0.002 \\
0.052 \\
0.504 \\
0.005\end{array}$ \\
\hline $\begin{array}{l}\text { Religion } \\
\text { Orthodox Christian } \\
\text { Muslim } \\
\text { Others }\end{array}$ & - & - & - & - & $\begin{array}{l}0.451 \\
0.789\end{array}$ & $\begin{array}{l}0.353 \\
0.607\end{array}$ & $\begin{array}{l}0.577 \\
1.026\end{array}$ & $\begin{array}{l}0.000 \\
0.000 \\
0.077\end{array}$ \\
\hline
\end{tabular}

Note: Model I = maternal health services variables; Model 2 = maternal health services and socio-demographic variables.

Interestingly, we found that Ethiopian mothers receiving the tetanus vaccine during pregnancy were significantly more likely to have their children fully immunized. Neonatal tetanus is a major cause of infant mortality in many developing countries, oftentimes due to failure to observe hygienic procedures during delivery. ${ }^{24,25}$ Therefore, WHO recommends that a pregnant woman, who has not previously been vaccinated or if her immunization status is unknown, should receive at least two doses of the tetanus vaccine, 1 month apart with the second dose given at least 2 weeks prior to delivery. ${ }^{34}$ A recent national study on early childhood mortality in Ethiopia reported that giving two tetanus vaccines to mothers before childbirth significantly decreased mortality. ${ }^{45}$ However, the tetanus immunization coverage at the national level is still only $49 \%{ }^{46}$

Additionally, this study found that certain sociodemographic characteristics such as the wealth index and a mother's education were key influencers in the full immunization of children in Ethiopia. Previous studies support our findings. The association between wealth status and

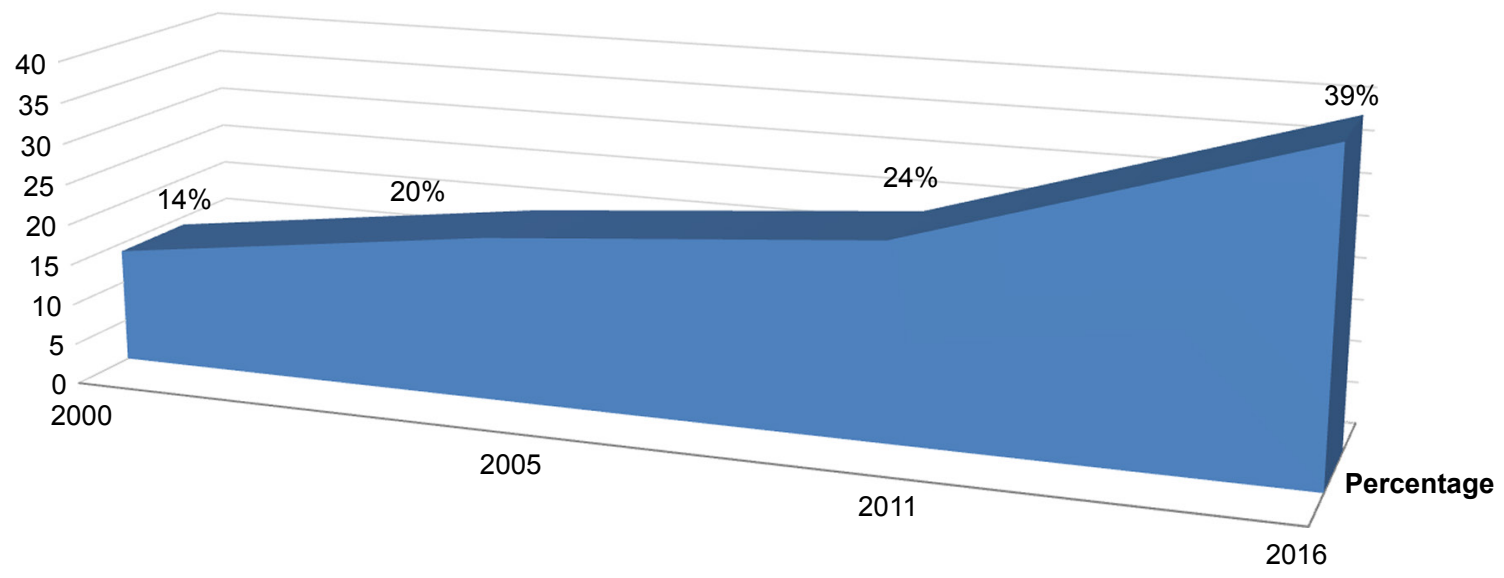

Figure I National trends of full immunization coverage in Ethiopia (2000-2016). 
childhood immunizations has been widely documented. Two studies in Ethiopia found that there was a $40 \%$ increase in the likelihood of receiving full vaccination among children born to mothers of the richest compared to the poorest wealth index group. ${ }^{27,47}$ Similarly, it has been reported that a mother's completion of primary level education was enough to predict the likelihood of complete immunization for her children. ${ }^{5,39-41}$ These outcomes are attributed to the fact that wealth and especially education empower women to make important decisions in the healthcare management of their children, including immunizations.

\section{Implications for practice}

Given the unacceptably high childhood mortality rates in Ethiopia, greater access and wider use of immunizations can prove important in helping to reduce the burden of vaccinepreventable disease, improve health-related outcomes, and advance quality of life. This study found that future national immunization initiatives need to concentrate in improving access to the following three key maternal health services: antenatal care, delivery services, and tetanus vaccine. Therefore, governmental action is needed to increase awareness, engage in outreach of rural, poor, and low educated women, and build capacity in their communities that emphasize the benefits of full immunization for their children. Additionally, it is recommended establishing a comprehensive and integrated approach between maternal health and child immunization services in the actual service delivery setups, to make it convenient for patients (mothers and their children) to receive vaccinations and strengthen the collaboration among staff serving the under-resourced primary healthcare settings in Ethiopia.

\section{Strengths and limitations}

This study has several significant strengths. It is one of the very first studies to use a large, nationwide, representative data set. Our findings can be used to provide excellent insight, policy recommendations, and plan immunization programs in Ethiopia. This study also has a number of limitations. First, it is a cross-sectional study, and therefore, its findings cannot infer causality or temporality. Second, despite the use of different strategies to reduce recall bias, participating mothers may have under/overestimated their child's immunization coverage. Third, this study did not examine economic or supply-related factors, which impact access and/or availability to vaccines and, therefore, may contribute to the low immunization coverage observed in many developing countries, including Ethiopia.

\section{Conclusion}

Full immunization coverage has been identified as a critical factor in the prevention of morbidity and mortality from childhood diseases. This study found that only $38 \%$ of children aged 12-23 months received their full immunizations in Ethiopia. Future progress in the provision of key maternal health services can have a positive impact in narrowing the gap in child immunization coverage. This could be supported by integration of healthcare services and improving maternal education and knowledge through community literacy and outreach programs.

\section{Data sharing statement}

Data are available through permission from ORC Macro International Inc.

\section{Acknowledgment}

The authors would like to gratefully acknowledge ORC Macro International Inc. (USA) and the Central Statistical Agency (Ethiopia) for their kind permission to use the data.

\section{Author contributions}

All authors contributed to data analysis, drafting and revising the article, gave final approval of the version to be published, and agree to be accountable for all aspects of the work.

\section{Disclosure}

The authors report no conflicts of interest in this work.

\section{References}

1. Abir T, Ogbo FA, Stevens GJ, Page AN, Milton AH, Agho KE. The impact of antenatal care, iron-folic acid supplementation and tetanus toxoid vaccination during pregnancy on child mortality in Bangladesh. PLoS One. 2017;12(11):e0187090.

2. Jokhio AH, Winter HR, Cheng KK. An intervention involving traditional birth attendants and perinatal and maternal mortality in Pakistan. NEngl J Med. 2005;352(20):2091-2099.

3. Wang H, Bhutta ZA, Coates MM, et al. Global, regional, national, and selected subnational levels of stillbirths, neonatal, infant, and under-5 mortality, 1980-2015: a systematic analysis for the Global Burden of Disease Study 2015. The Lancet. 2016;388(10053):1725-1774.

4. Khan AA, Zahidie A, Rabbani F. Interventions to reduce neonatal mortality from neonatal tetanus in low and middle income countries a systematic review. BMC Public Health. 2013;13(1):322.

5. Mbengue MAS, Sarr M, Faye A, et al. Determinants of complete immunization among senegalese children aged 12-23 months: evidence from the demographic and health survey. BMC Public Health. 2017; 17(1):630.

6. World Health Organization (WHO). United Nations Children's Fund (UNICEF). Global Immunization Data. Geneva: WHO; 2014. Available from: http://www.who.int/immunization/monitoring_surveillance/ global_immunization_data.pdf. Accessed December 6, 2018.

7. Danielsson N, Fakakovikaetau T, Szegedi E. Improved immunization practices reduce childhood hepatitis $\mathrm{B}$ infection in Tonga. Vaccine. 2009;27(33):4462-4467. 
8. Lee EHJ, Lewis RF, Makumbi I. Haemophilus influenzae type b conjugate vaccine is highly effective in the Ugandan routine immunization program: a case-control study. Trop Med Int Health. 2008;13(4):495-502.

9. WHO [webpage on the Internet]. Global Immunization Coverage. Available from: http://www.who.int/gho/immunization/en/. Accessed September 5, 2018.

10. United Nations Inter-agency Group for Child Mortality Estimation (UN IGME) [homepage on the Internet]. Levels \& Trends in Child Mortality Report. Available from: http://www.childinfo.org. Accessed July 1, 2018.

11. Federal Ministry of Health (FMOH). Ethiopia National Expanded Programme on Immunization. Addis Ababa: Comprehensive Multi-Year Plan 2011-2015; 2010.

12. World Health Organization. World Health Report 2005. Geneva, Switzerland: WHO; 2005.

13. Federal Democratic Republic of Ethiopia. Comprehensive Multiyear Plan 2016-2020 Com. Addis Ababa: Federal Ministry of Health, Addis Federal Ministry of Health; April 20, 2015.

14. Federal Democratic Republic of Ethiopia-Country Profile. Country Profile of Federal Democratic Republic of Ethiopia; 2013.

15. Boulton ML, Carlson BF, Power LE, Wagner AL. Socioeconomic factors associated with full childhood vaccination in Bangladesh, 2014. Int J Infect Dis. 2018;69:35-40.

16. Berhane Y, Masresha F, Zerfu M, Birhanu M, Kebede S, Shashikant S. Status of expanded program on immunization in a rural town - south Ethiopia. Ethiop Med J. 1995;33(2):83-93.

17. Mohamud AN, Feleke A, Worku W, Kifle M, Sharma HR. Immunization coverage of 12-23 months old children and associated factors in Jigjiga District, Somali National Regional State, Ethiopia. BMC Public Health. 2014;14(1):865.

18. Legesse E, Dechasa W. An assessment of child immunization coverage and its determinants in Sinana District, Southeast Ethiopia. BMC Pediatr. 2015;15(1):31.

19. Friede AM, Waternaux C, Guyer B, De Jesus A, Filipp LC. An epidemiological assessment of immunization programme participation in the Philippines. Int J Epidemiol. 1985;14(1):135-142.

20. Haque Raysul SM, Wasimul B. Positive role of maternal education on measles vaccination coverage in Bangladesh. Int J Psychol Behav Sci. 2015;3(1):1-7.

21. Afzal N, Zainab B. Determinants and status of vaccination in Bangladesh. Dhaka Univ J Sci. 2012;60(1):47-51.

22. Rahman M, Obaida-Nasrin S. Factors affecting acceptance of complete immunization coverage of children under five years in rural Bangladesh. Salud Pública de México. 2010;52(2):134-140.

23. Biswas SC, Abu Darda M, Alam MF. Factors affecting childhood immunisation in Bangladesh. The Pakistan Development Review. 2001; 40(1):57-70.

24. Singh A, Pallikadavath S, Ogollah R, Stones W. Maternal tetanus toxoid vaccination and neonatal mortality in rural north India. PLoS One. 2012; 7(11):e48891.

25. Koenig MA, Roy NC, Mcelrath T, Shahidullah M, Wojtyniak B. Duration of protective immunity conferred by maternal tetanus toxoid immunization: further evidence from Matlab, Bangladesh. Am J Public Health. 1998;88(6):903-907.

26. Funmilayo A. Determinants of Full Child Immunization Among 12-23 Months Old in Nigeria [MSc thesis]. Johannesburg: University of the Witwatersrand. Demography and Population Studies Department; 2015.

27. Lakew Y, Bekele A, Biadgilign S. Factors influencing full immunization coverage among 12-23 months of age children in Ethiopia: evidence from the national demographic and health survey in 2011. BMC Public Health. 2015;15(1):728.

28. Rutstein SO, Rojas G. Guide to DHS Statistics. Demographic and Health Surveys Methodology; 2006:61. Available from: https://dhsprogram.com/pubs/pdf/DHSG1/Guide_to_DHS_Statistics_29Oct2012_ DHSG1.pdf. Accessed July 17, 2018.
29. United Nations (UN) [webpage on the Internet]. Department of Economic and Social Affairs: Population Division; 2017. Available from: https://population.un.org/wpp. Accessed October 16, 2018.

30. Central Statistical Agency (CSA) and ORC Macro Inc. Ethiopia Demographic and Health Survey 2016. Addis Ababa, Ethiopia and Calverton, Maryland: USACSA and ORC Macro; 2016.

31. World Bank. Maternal and Child Health Inequalities in Ethiopia. Social Protection and Labor Global Practice Group December. Policy Research Working Paper, No 7508; 2015.

32. Ministry of Health of the Federal Democratic Republic of Ethiopia. Health Sector Development Program IV/HSDP IV, Addis Ababa, Ethiopia; 2015.

33. WHO: Federal Democratic Republic of Ethiopia. Country Cooperation Strategy at a Glance. Available from: http://apps.who.int/iris/ handle/10665/137170. Accessed December 13, 2018.

34. WHO [webpage on the Internet]. WHO Recommendation on Tetanus Toxoid Vaccination for Pregnant Women. Available from: https:// extranet.who.int/rhl/topics/preconception-pregnancy-childbirth-andpostpartum-care/antenatal-care/who-recommendation-tetanus-toxoidvaccination-pregnant-women. Accessed October 29, 2018.

35. Greenland S. Modeling and variable selection in epidemiologic analysis. Am J Public Health. 1989;79(3):340-349.

36. Hosmer DW, Hosmer T, Le Cessie S, Lemeshow S. A comparison of goodness-of-fit tests for the logistic regression model. Stat Med. 1997; 16(9):965-980.

37. WHO. Diphtheria-tetanus-pertussis (DPT3) immunization coverage; 2017. Available from: https:/www.who.int/gho/immunization/dtp3/ en/. Accessed July 1, 2018.

38. Kazungu JS, Adetifa IMO. Crude childhood vaccination coverage in West Africa: trends and predictors of completeness. Wellcome Open Res. 2017;2:12.

39. Mebrahtom S, Birhane Y. Magnitude and determinants of childhood vaccination among pastoral community in Amibara District, Afar Regional State, Ethiopia. Res J Med Sci Pub Health. 2013;1(3):22-35.

40. Etana B, Deressa W. Factors associated with complete immunization coverage in children aged 12-23 months in Ambo Woreda, Central Ethiopia. BMC Public Health. 2012;12(1):1-9.

41. Abdulraheem IS, Onajole AT, Jimoh AAG, Oladipo AR. Reasons for incomplete vaccination and factors for missed opportunities among rural Nigerian children. J Public Health Epidemiol. 2011;3(4): 194-203.

42. Koumaré AK, Traore D, Haidara F, et al. Evaluation of immunization coverage within the Expanded Program on Immunization in Kita Circle, Mali: a cross-sectional survey. BMC Int Health Hum Rights. 2009; 9(Suppl 1):S13.

43. Babalola S, Lawan U. Factors predicting BCG immunization status in northern Nigeria: a behavioral-ecological perspective. J Child Health Care. 2009;13(1):46-62.

44. Saxena P, Prakesh D, Saxena V, Kansal S. Assessment of routine immunization in urban slum of Agra district. India Journal of Prev Med. 2008;39(1):12-15.

45. Mekonnen Y, Tensou B, Telake DS, Degefie T, Bekele A. Neonatal mortality in Ethiopia: trends and determinants. BMC Public Health. 2013;13(1):483.

46. Anatea MD, Mekonnen TH, Dachew BA. Determinants and perceptions of the utilization of tetanus toxoid immunization among reproductiveage women in Dukem Town, Eastern Ethiopia: a communitybased cross-sectional study. BMC Int Health Hum Rights. 2018; 18(1):27.

47. Rainey JJ, Watkins M, Ryman TK, Sandhu P, Bo A, Banerjee K. Reasons related to non-vaccination and under-vaccination of children in low and middle income countries: findings from a systematic review of the published literature, 1999-2009. Vaccine. 2011;29(46): $8215-8221$ 
Patient Preference and Adherence

Dovepress

\section{Publish your work in this journal}

Patient Preference and Adherence is an international, peer-reviewed, open access journal that focuses on the growing importance of patient preference and adherence throughout the therapeutic continuum. Patient satisfaction, acceptability, quality of life, compliance, persistence and their role in developing new therapeutic modalities and compounds to optimize

Submit your manuscript here: http://www.dovepress.com/patient-preference-and-adherence-journ clinical outcomes for existing disease states are major areas of interest for the journal. This journal has been accepted for indexing on PubMed Central. The manuscript management system is completely online and includes a very quick and fair peer-review system, which is all easy to use. Visit http://www. dovepress.com/testimonials.php to read real quotes from published authors. 